\title{
Adherence with the Processes of Time Management in Construction Project Delivery in Nigeria
}

\author{
Suleiman Shehu*1, Abdullahi Nafiu Zadawa², Abdullahi Yusuf Waziri ${ }^{3}$, Rabiu Shehu ${ }^{4}$ \\ ${ }^{1,2,3}$ Department of Quantity Surveying, \\ ${ }^{4}$ Department of Building Technology, \\ Faculty of Environmental Technology, \\ Abubakar Tafawa Balewa University Bauchi, Nigeria \\ *Corresponding Author: ssuleiman088@gmail.com
}

\begin{abstract}
The management of time is a necessity of life. Project time management includes the processes required to manage the timely completion of the project. However, in the construction sector such as in Nigeria, poor delivery of project especially completion within schedule has remained an issue, despite established processes of time management. The crux of this study is to investigate adherence with the processes of time management in construction project delivery in Nigeria and the objectives are: to assess the level of adherence with the processes of time management, and to determine the effect of adherence with the processes of time management on construction project timely completion. The study was conducted in Gombe State, Nigeria. Stratified random sampling technique was used to administer 88 questionnaires to professionals such as: the Architects, Builders, Quantity surveyors, Engineers and Project managers who were personnel working for the client, consultants and contractors in various projects locations in the study area. The data collected was analyzed with SPSS software using weighted mean score, one sample t-test and regression. Findings revealed that the most adhered processes of time management are: monitoring and controlling the project schedule, estimating resource requirement for activities and developing schedule of the project. Adherence with the processes of time management will lead to $15.4 \%$ caused effect increase on timely completion of project. As such, it is recommended that construction stakeholders should collaborate and adhered strictly with all the established processes of time management as a guide in order to ensure successful completion of construction project within schedule in Nigeria.
\end{abstract}

Keywords: Adherence, Construction Project Delivery, Processes, Time management

\section{Introduction}

The management of time is a necessity of life. In the construction industry stakeholders are unanimous that time along with cost and quality are the major deliverables upon which project are said to be a success or failure. Project management is the application of knowledge, skills, tools, and techniques to project activities to meet the project requirements and is accomplished through the appropriate application and integration of the project management processes identified for the project (Project management institute [PMI], 2013). The project management process begins with identification of the user requirement, project constraints, resource needs, and establishment of realistic objectives to meet the strategic goals (Federal Transit 
Administration [FTA], 2012). Hence, Project Management Processes: are set of interrelated actions and activities performed to achieve a pre-specified product, system, result, or service (FTA, 2012). Each process is characterized by its inputs, the tools, and techniques that can be applied and the resulting outputs (PMI, 2013). In addition, the Project management processes are grouped into five categories: initiating, planning, executing, monitoring and controlling, and closing group (PMI, 2013). Basically, they are used throughout the life cycle of a project. Construction has been facing numerous issues and one of them is time management issues which have caused delayed completion of a project (Chin \& Abdulhamid, 2015). Lack of time management can and probably will result in failure of a project PMI (2017). A research conducted by the Chartered Institute of Building (CIOB) in 2008 has indicated that the quality of time-management on construction projects is generally poor (Chin \& Abdulhamid, 2015).

However, in the construction sector such as in Nigeria, poor delivery of project especially completion within schedule has remained an issue causing disharmony among construction stakeholders despite the existence of established processes of time management. Although, Hussain (2014) in his studies reviewed the main tools and techniques that are used in implementing the processes of time management. However, none of the studies reviewed within and outside Nigeria has deliberated on the level of adherence with the processes of time management. Therefore, this study is a solution oriented towards adhering with established processes that will influence construction project and reduced delay. As such, this study filled the gap by investigating adherence with processes of time management in construction project delivery in Nigeria and the objectives are: to assess the level of adherence with the processes of time management and ranked in order of importance, and to determine the effect of adherence with the processes of time management on construction project timely completion.

\section{Literature Review}

\section{The Concept of Project Time Management}

Time management is basically a set of principles, practices, skills, tools and system that helps one to use one's time to accomplish what one wants. Project time management includes the processes required to manage the timely completion of the project (PMI, 2013). In addition, the better time is managed the more efficient a project will be, assuming all others processes remain the same PMI (2017). The project management institute has done a great deal in clarifying the processes required in project time management. According to PMI (2013), there are seven (7) project time management processes, which include: (a) Plan Schedule Management (b) Define Activities (c) Sequence Activities (d) Estimate Activity Resources (e) Estimate Activity Durations (f) Develop Schedule (g) Control Schedule. The processes of time management also include all the necessary inputs, tools and techniques, outputs and activities involved Hussain (2014), (PMI, 2013), and Passenheim (2009). Table 1 depict an elaborate processes involved in project time management.

\section{Table 1: An Elaborate Processes of Project Time Management}

\begin{tabular}{ll}
\hline Factors & Activities Involve \\
\hline $\begin{array}{l}\text { 1. Plan Schedule } \\
\text { Management }\end{array}$ & $\begin{array}{l}\text { The process of establishing the policies, procedures, and documentation for } \\
\text { planning, developing, managing, executing, and controlling the project } \\
\text { schedule. }\end{array}$
\end{tabular}


2. Define Activities

3. Sequence Activities

4. Estimate Activity Resources

5. Estimate Activity Durations

6. Develop Schedule

7. Control Schedule

- The process of identifying and documenting the specific actions to be performed to produce the project deliverables.

- The process of identifying and documenting relationships among the project activities.

- The process of estimating the type and quantities of material, human resources, equipment, or supplies required to perform each activity.

- The process of estimating the number of work periods needed to complete individual activities with the estimated resources.

- The process of analyzing activity sequences, durations, resource requirements, and schedule constraints to create the project schedule model for project execution and monitoring and controlling.

- The process of monitoring the status of the project to update the project schedule and manage changes to the schedule baseline.

Source: Adapted Hussain (2014), (PMI, 2013), and Passenheim (2009)

\section{The Concept of Construction Project Delivery}

Construction deliverables are the ultimate aim of any project and they formed the benchmark upon which the success or failure of a project are appraised by stakeholders in the construction sector. Chan and Kumaraswamy (2002) state that timely completion of construction projects within anticipated cost and to the level of quality standards settled by the owner is an index of successful project delivery. Ibironke and Elamah (2011) on their part opined that, client when engaging professionals for the purpose of procuring a building or other infrastructure are primarily concerned about quality, time and cost. In addition, Ibrahim (2020) and Hao, Shen, Neelamkavil and Thomas (2008) reports that more than a third of major clients are dissatisfied with contractors' performance in keeping to the quoted price and to time, resolving defects, and delivering a final product of the required quality. Abdulkadir, Muhammad, Gidado and Nuruddeen (2017) in their studies of cost and time overrun of building projects in Nigeria, also reported poor time performance rate of (21-40) \% of projects executed. In addition, John, Abdullateef and Abdulganiyu (2015), in their studies of time and cost relationship of private building projects in Abuja, Nigeria report an average time overrun of 34\% project duration. According to Murithi, Makokha and Otieno (2017), timely project completion is the projected completion time as in the contract for the construction of the project.

\section{Theoretical Framework}

Time management is not actually managing time per se, but how one manages his own behaviour and activities in relation to time. As such this study was guided by the theories of management and behaviour.

Management theories were concerned with the formal relations among organization's departments, tasks and processes and the promotion of greater efficiency and productivity among workers (Kwok, 2014). In addition, these theories which include bureaucratic, administrative and scientific management all emerged around the same period around the late 1890s to early 1990s (Kwok, 2014). This study adopts the administrative and scientific management theories as against the bureaucratic which is a rigid approach to management. According to Kwok (2014), Administrative management is more concerned with how an organization is run and the distinction of basic managerial functions. Henri Fayol (1841-1925), a French industrialist, was the first person to group management functions that today are 
summarized as planning, organizing, leading, coordinating, controlling and staffing. According to Kwok (2014), the scientific management theory focused primarily on production, management, organization, technology and science and is probably the most well-known among the traditional theories, and comprises of four basic objectives, as follows: (i) The development of a science for each element of a man's work to replace the old rule-of thumb methods (ii) The scientific selection, training and development of workers instead of allowing them to choose their own tasks and train themselves as best they could (iii) The development of a spirit of hearty cooperation between workers and management to ensure that work could be carried out in accordance with scientifically devised procedures and (iv) The division of work between workers and the management in almost equal shares, each group taking over the work for which it is best fitted instead of the former condition in which responsibility largely rested with the workers. Kwok (2014), state that, major contributors to scientific management theories are: Frederick Winslow Taylor (1856-1915), Henry Gantt (1861-1919), Frank Gilbreths (1868-1924) etc.

According to Kwok (2014), the behavioural theories which emerged in 1920's stress the importance of group dynamics, complex human motivations and the manager's leadership style. The theory also emphasizes on the employee's social and economic needs and the influence of the organization's social setting on the quantity and quality of work produced, and its focuses on two competencies- communication and teamwork. Kwok (2014), list Elton Mayo (1880-1949), Abraham Maslow (1908-1970), Douglas McGregor (1906-1964), Frederick Herzberg (1923-2000), David McClelland (1917-1998) etc. as major contributors to behavioural theories.

As adapted for this study, both the management and behavioural theories has stressed the importance of adhering with certain principles, processes and practices that will ensure effective and efficient project operation with the resultant success in project delivery. The management and behavioural theory are in consonance with Ugwu and Attah (2016) they identified economic policy, political consideration, management style and motivation of workers as relevant in construction management. As such, to ensure successful construction project delivery there is need for a holistic approach in terms of managing ourselves towards time "Behavioural" and managing construction activities "administratively and scientifically".

\section{Conceptual Framework}

Figure 1 presents the conceptual framework for the study. It has two major components. Which are: The Independent Variable (IV) - Adherence with the processes of time management and Dependent Variable DV) - Construction project delivery. The frame work postulates that the "IV" will ensure effective and efficient project operation which will directly affects the "DV" i.e. timely completion of construction project. However, this relationship is not immune to external factors which may affect its smooth operation. 
Independent Variable (IV)

Dependent Variable (DV)

\section{Adherence with the Processes of Time Management}

Construction Project Delivery

- Timely completion

Figure 1: Conceptual Framework of the Study

Source: Author

\section{Methodology}

This study adopted a quantitative research approach, using questionnaire as an instrument for data collection. Literature review was carried out to obtained information on the processes of time management and construction project delivery which were presented in the questionnaire. The questionnaire seeks to gather information regarding the level of adherence with processes of time management in construction project delivery in Nigeria. A 6-point likert scale (1-6) of non-adherence to adherence was used to give participants more equal freedom as well as to avoid the use of "medium/neutral" which might be subjective for this type of study. Also, Low: 1-30\%, Medium: 31-60\% and High: $61-100 \%$ was used to remark the respondents' level of agreement. Stratified random sampling technique was adopted to understand the perception of 88 professionals such as: The Architects, Builders, Quantity surveyors, Engineers, Project managers working as personnel for the client, consultant and contractors involved in handling construction projects in Federal University Kashere ( $\mathrm{FUK}=30$ No.), Federal College of Education Technical (FCET=23 No.) and other firms of consultants and contractors (35 No.) all situated in Gombe state, North Eastern Nigeria. The questionnaire attains $70 \%$ response rate equivalent to 62 number correctly completed and returned. The participants were surveyed regarding their level of adherence or willingness to adhere with the processes of time management. The data obtained was analyzed using statistical package for social science (SPSS) software using descriptive statistics, Mean scores and t-test to establish the level of importance of the sample factors and ranked according to their importance index. Regression was used to determine the factors effects on timely completion of construction project. The factors with the highest mean scores values are considered the most adhered processes of time management in construction project delivery in Nigeria.

\section{Results and Findings}

Table 2, shows that a total of 88 questionnaires were distributed of which 62 questionnaires were retrieved which represent $70.45 \%$ response rate which was used for data analysis of the study. This excellent response rate above average was achieved as a result of the face-to-face method of questionnaire administration used, simplicity of language and distributing the questionnaires to the right respondents. The result further revealed that, 26 questionnaires were either spoiled or not returned representing $29.55 \%$. This response rate for this type of survey is higher than other studies carried out in the construction industry. Such as: Abdulkadir et al. (2017) 56\% response rate; Ayodeji, Eseohe, Opeyemi, Ebenezer, Amusan and Abisola (2017) $64 \%$ response rate; Olawale and Sun (2010) 44\% response rate and Amade, Ubani, Omajeh and Njoku, (2015) recorded $61 \%$ response rate. 
Table 2: Questionnaire Response Rate

\begin{tabular}{lcccc}
\multicolumn{1}{c}{ Respondents } & Distribution (No) & Distribution (\%) & Returned (No) & Returned (\%) \\
\hline FCET & 23 & 26.1 & 18 & 78.3 \\
FUK & 30 & 34.1 & 26 & 86.7 \\
Firms & 35 & 39.8 & 18 & 51.4 \\
Total & $\mathbf{8 8}$ & $\mathbf{1 0 0}$ & $\mathbf{6 2}$ & \\
\hline
\end{tabular}

Source: Author

"Response rate $=$ No. of questionnaires returned $\div$ No. of questionnaires distributed $x$ 100"

\section{Reliability and Validity Test}

The use of Cronbach's $\alpha$, allows negative construct to be detected and positive to be accepted ranging from a scale of 0 to 1.0 (Ogwueleka, 2011 cited in Inuwa, 2014). The minimum acceptable value for Cronbach's alpha is ranges from 0.5 to 0.6 (Inuwa, 2014). In addition, < 0.5 indicates Poor reliability; 0.5-0.7 sufficient reliability and $>0.7$ indicates good reliability. Therefore, Cronbach's $\alpha$ scale is used to measure the study questionnaire construct consistency (reliability) and level of random error emanating thereof.

Validity test was conducted on the research questionnaire through the panel of four professional judges with relevant years of working experience in construction project, with two academicians and two construction field experts. The observations and remarks made, has contributed immensely towards ensuring the questionnaire is valid enough to get the necessary data from the study respondents.

Table 3, the Cronbach's $\alpha$ measure recorded for this study revealed that the reliability of the questionnaires' constructs are very high, 0.88 exceeding the cut off score of 0.70 , which is the standard used by most researchers for high efficiency. This indicates that the questionnaires are highly reliable (consistent) as well as free from random error.

Table 3: Cronbach's $\alpha$ and Reliability Status

\begin{tabular}{llccc}
\hline S/N & Factor category & No. of Items & Cronbach's $\boldsymbol{\alpha}$ & Status \\
\hline 1 & Processes of time management & 7 & 0.88 & Good \\
\hline
\end{tabular}

Source: Author

Table 4, presents the background information of the respondents. Findings revealed that majority of the respondents $61.3 \%$ have Degree/HND; 30.6\% have Masters/PGD; as such virtually all the respondents have the requisite academic qualification. Hence, their assessment is valid. On the area of specialization, virtually all the relevant professions were adequately represented with Engineering and Quantity surveying having $22.6 \%$ each, Architecture $19.4 \%$, Building 14.4\%, while Project management and other relevant professionals account for $21 \%$. On the years of working experience, all the respondents have the requisite years of experience in the construction industry with $37.10 \%$ having 6-10years, $25.80 \%$ having 11 -15years while $12.9 \%$ have more than 15years working experience. As such by virtue of experience, the respondents' are competent enough to have participated in the survey and therefore, has ensured high reliability of the results. On the category of working organization, 39\% are working for the client; $29 \%$ for the consultants and $32 \%$ works for the contractors. As such, all the major players in a typical construction project are equally represented which has reduced biasness of any sort. On the extension of time, all the participants have experienced delay with $41.94 \%$ reporting $1-6$ months, $37.10 \%$ 6-12months delayed and $11.29 \%$ reported more than 
18 months delayed in project completion time. As such, time overrun is still a major issue affecting construction projects delivery in Nigeria.

\section{Table 4: Background Information of the Respondents}

\begin{tabular}{|c|c|c|}
\hline Characteristics & Frequency (No) & Percentage (\%) \\
\hline \multicolumn{3}{|l|}{ Area of specialization } \\
\hline Architecture & 12 & 19.4 \\
\hline Engineering & 14 & 22.6 \\
\hline Quantity surveying & 14 & 22.6 \\
\hline Building & 9 & 14.4 \\
\hline Project Management/others & 13 & $21 \%$ \\
\hline Total & 62 & 100 \\
\hline \multicolumn{3}{|c|}{ Highest qualification obtained } \\
\hline $\mathrm{NCE} / \mathrm{ND}$ & 2 & 3.2 \\
\hline Degree/HND & 38 & 61.3 \\
\hline Masters/PGD & 19 & 30.6 \\
\hline $\mathrm{PhD}$ & 3 & 4.8 \\
\hline Total & 62 & 100 \\
\hline \multicolumn{3}{|l|}{ Years of working experience } \\
\hline $0-5$ years & 15 & 24.2 \\
\hline $6-10$ years & 23 & 37.1 \\
\hline $11-15$ years & 16 & 25.8 \\
\hline More than 15 years & 8 & 12.9 \\
\hline Total & 62 & 100 \\
\hline \multicolumn{3}{|c|}{ Category of working organization } \\
\hline Client & 24 & 38.7 \\
\hline Consultant & 18 & 29 \\
\hline Contractors & 20 & 32.3 \\
\hline Total & 62 & 100 \\
\hline \multicolumn{3}{|l|}{ Experienced time overrun } \\
\hline Yes & 62 & 100 \\
\hline Total & 62 & 100 \\
\hline \multicolumn{3}{|l|}{ Length of time extension } \\
\hline 0 months & 1 & 1.6 \\
\hline $1-6$ months & 26 & 41.9 \\
\hline $6-12$ months & 23 & 37.1 \\
\hline $12-18$ months & 5 & 8.1 \\
\hline more than 18 months & 7 & 11.3 \\
\hline Total & 62 & 100 \\
\hline
\end{tabular}

Source: Author

Table 5, is the representation of the respondents' ratings on the level of adherence with the processes of time management in percentages. The study reveals that $84.81 \%$ of the respondents claimed to be adhering or willing to adhere with the processes of time management as against $15.19 \%$ who are unwilling to adhere with the processes. The results further revealed that, virtually all the seven factors constituting the processes of time management have a high score of more than $70 \%$ rate in terms of agreement by the respondents. 
Table 5: Respondents levels of Adherence with the Processes of Time Management

\begin{tabular}{|c|c|c|c|c|c|c|c|c|c|c|}
\hline \multirow{2}{*}{ Processes of time management } & \multicolumn{4}{|c|}{ Non-Adherence (\%) } & \multicolumn{4}{|c|}{ Adherence (\%) } & \multirow{2}{*}{ Total } & \multirow{2}{*}{ Remark } \\
\hline & 1 & 2 & 3 & Sum & 4 & 5 & 6 & Sum & & \\
\hline Plan schedule management & & 4.8 & 14.5 & 19.3 & 25.8 & 32.3 & 22.6 & 80.7 & 100 & High \\
\hline Define activities to be undertaken & 1.6 & 3.2 & 11.3 & 16.1 & 38.7 & 32.3 & 12.9 & 83.9 & 100 & High \\
\hline Sequencing of activities & & 9.3 & 13.1 & 22.4 & 25.8 & 33.9 & 17.9 & 77.6 & 100 & High \\
\hline Estimating resource requirement for activities & & 6.5 & 3.2 & 9.7 & 29.0 & 38.7 & 22.6 & 90.3 & 100 & High \\
\hline Estimating duration of activities & & 6.5 & 11.3 & $\mathbf{1 7 . 8}$ & 27.3 & 32.3 & 22.6 & 82.2 & 100 & High \\
\hline Developing schedule for the project & 1.6 & 1.6 & 6.5 & 9.7 & 25.8 & 51.6 & 12.9 & 90.3 & 100 & High \\
\hline Monitoring and controlling schedule & & 1.6 & 9.7 & 11.3 & 29.0 & 32.3 & 27.4 & 88.7 & 100 & high \\
\hline Total & & & & 15.19 & & & & 84.81 & 100 & \\
\hline
\end{tabular}

-Never Adhere $=1$, Very Rarely $=2$, Rarely $=3$, Occasionally $=4$, Frequently $=5$, Very Frequently $=6$

- Remark "Level of Agreement": Low: 1-30\%, Medium: 31-60\% and for High: $61-100 \%$

Source: Author

Table 6, is a representation of the mean scores and rankings on the processes of time management. Findings revealed that, Monitoring and controlling schedule of the project, with (Mean 4.74 \& Standard Deviation "SD" 1.023) was ranked "first". Estimating resource requirement for activities, with (Mean 4.68 \& SD 1.023) was ranked "second". Developing schedule for the project, with (Mean 4.63 \& SD 0.92 ) was ranked "third". Estimating duration of activities, with (Mean 4.53 \& SD 1.155) was ranked "fourth". Plan schedule management, with (Mean 4.53 \& SD 1.141) was ranked "fifth". Sequencing of activities, with (Mean 4.35 \& SD 1.243) was ranked "sixth" and Define activities to be undertaken, with (Mean 4.35 \& SD 1.057) was the least important and was ranked "seventh". An independent samples t-test was also used to generate the tvalue and the p-value (significance) in order to ascertain the degree of discrepancies with respect to each variable in the responses of respondents. Using a test value of 4.00 , the one sample t-test statistics was carried out in order to investigate the significance attached to the level of adherence with the processes of time management by the respondents. Findings revealed that at $p<0.05$, all the 7 factors constituting the processes of time management shows significant importance as all their $\mathrm{p}$-values are less than the recommended 0.05 value. 
Table 6: Mean Scores and Ranking on the Processes of Time Management

\begin{tabular}{|c|c|c|c|c|c|c|}
\hline Factors & Mean & Std. Dev. & Rank & $\mathbf{T}$ & $\begin{array}{c}\text { Mean diff } \\
\text { (test value }=4)\end{array}$ & Sig \\
\hline $\begin{array}{l}\text { - } \begin{array}{l}\text { Monitoring and controlling } \\
\text { schedule }\end{array}\end{array}$ & 4.74 & 1.023 & 1 & 5.71 & 0.74 & .000 \\
\hline $\begin{array}{l}\text { Estimating resource } \\
\text { requirement for activities }\end{array}$ & 4.68 & 1.068 & 2 & 5.15 & 0.63 & .000 \\
\hline $\begin{array}{l}\text { - Developing schedule for the } \\
\text { project }\end{array}$ & 4.63 & 0.962 & 3 & 5.00 & 0.68 & .000 \\
\hline - Estimating duration of activities & 4.53 & 1.155 & 4 & 3.67 & 0.53 & .001 \\
\hline - Plan schedule management & 4.53 & 1.141 & 5 & 3.63 & 0.53 & .001 \\
\hline - Sequencing of activities & 4.35 & 1.243 & 6 & 2.64 & 0.35 & .010 \\
\hline $\begin{array}{l}\text { - Define activities to be } \\
\text { undertaken }\end{array}$ & 4.35 & 1.057 & 7 & 2.25 & 0.35 & .028 \\
\hline Grand mean $=$ & 4.54 & & & & & \\
\hline
\end{tabular}

Source: Author

Table 7, is the regression model summary of the independent variable i.e. processes of time management. It shows R-Value of 0.423 and R-Square value of 0.179 which explains $17.9 \%$ of the variance $(0.179 \times 100 \%)$. The implication of this model is that adherence with the processes of time management alone accounts for only $17.9 \%$ while other factors not covered in this study will account for the remaining variables.

Table 7: Regression Model Summary

\begin{tabular}{lcccc}
\hline Model & R & R Square & Adjusted R Square & Std. Error of the Estimate \\
\hline 1 & .423 & 0.179 & 0.072 & 1.04183 \\
\hline Source: Author & & & &
\end{tabular}

Table 8 , is the regression coefficient of the independent variable i.e. processes of time management and dependent variable i.e. construction project timely completion. Findings revealed that a unit increase in the level of adherence with the processes of time management will lead to $15.4 \%$ cause effect increase in timely completion of construction projects i.e. having a $\beta$ (Beta) of 0.154 and $t=1.207$, even though is not significant.

Table 8: Regression Coefficients ${ }^{\mathrm{a}}$

\begin{tabular}{|c|c|c|c|c|c|}
\hline \multirow[t]{2}{*}{ Model } & \multicolumn{2}{|c|}{ Unstandardized Coefficients } & \multirow{2}{*}{$\begin{array}{c}\begin{array}{c}\text { Standardized } \\
\text { Coefficients }\end{array} \\
\text { Beta } \\
\end{array}$} & \multirow[t]{2}{*}{$\mathbf{t}$} & \multirow[t]{2}{*}{ Sig. } \\
\hline & B & Std. Error & & & \\
\hline (Constant) & 4.339 & 0.76 & & 5.708 & 0.000 \\
\hline $\begin{array}{l}\text { Processes of time } \\
\text { management }\end{array}$ & 0.028 & 0.023 & 0.154 & 1.207 & 0.232 \\
\hline
\end{tabular}

a. Dependent Variable: Construction project delivery (Timely Completion)

Source: Author

\section{Discussion of Results}

Data analysis and questionnaire responses from the respondents revealed that $84.81 \%$ of the respondents are adhering or willing to adhere while $15.19 \%$ were unwilling or not adhering 
with the processes of time management. 79\% of the respondents experienced delay of 112 months in project completion time.

However, monitoring and controlling schedule of the project; estimating resource requirement for activities and developing schedule for the project were the three most adhered processes of time management. In this study monitoring and controlling schedule of a project was ranked as the foremost adhered process of time management. The essential of monitoring and controlling project schedule has been echoed by PMI (2013), reporting that controlling schedule is the process of monitoring the status of project activities to update project progress and manage changes to the schedule baseline to achieve the plan, and the key benefit of this process is that it provides the means to recognize deviation from the plan and take corrective and preventive actions and thus minimize risk. Also, Murithi et al. (2017), in their studies of time management in Kenya, also echoed the importance of effective monitoring of project. Estimating resource requirement for activities was ranked as the second most adhered processes of time management in this study. The importance of determining the quality and quantity of various resources required to complete project on schedule has been echoed by PMI (2013) by reporting that, Estimate activity resources is the process of estimating the type and quantities of material, human resources, equipment, or supplies required to perform each activity. They further state that the key benefit of this process is that it identifies the type, quantity, and characteristics of resources required to complete the activity which allows more accurate cost and duration estimates. Mgeleka (2015) and Hussain (2014), also stressed the importance of effective resource requirement in their various studies respectively. Developing schedule for the project was ranked as the third most adhered processes of time management. PMI (2013) states that the key benefit of this process is that by entering schedule activities, durations, resources, resource availabilities, and logical relationships into the scheduling tool, it generates a schedule model with planned dates for completing project activities. The findings on the importance of developing schedule was in consonance with Sunke (2009), in his studies, assert that project schedule is not just a valuable instrument in communication and coordination of processes. It also serves both the planning of project activities and a related resource assignment to each activity considering some measure of performance as well as the planning of external activities.

The implication of these results is that adherence with the processes of time management most especially monitoring and controlling the project schedule, estimating resource requirement for the project activities and developing schedule of the project, with a combine mean scores of 14.05 equivalents to $44.17 \%$ overall total will lead to $15.4 \%$ caused effect increase on timely completion of construction project in Gombe state, Nigeria.

\section{Conclusion and Recommendation}

Timely delivery of construction project should be the business of every construction stakeholders - client, consultants and contractors per se. investigating the level of adherence with the processes of time management and its effect on timely completion of construction project is the crux of this study. Adherence with the processes of time management most especially monitoring and controlling project schedule, estimating resource requirement for activities and developing schedule of the project are crucial for effective construction project 
delivery. As such, the higher the level adherence with the processes of time management the more the possibility of completing construction project within schedule provided there is less interference from external influence. Based on the findings of this study, it is recommended that construction stakeholders should collaborate and adhered strictly with all the established processes of time management in order to ensure successful completion of construction project within schedule in Nigeria.

\section{References}

Abdulkadir, S., Muhammad, A. I., Gidado, U. M., \& Nuruddeen, U. (2017). Cost and time overrun in building projects: professional attitude and incidence rate in practice. International Journal of Economics, Commerce and Management, 5, 276-283.

Amade, B., Ubani, E. C., Omajeh, E. O.-M., \& Njoku, U. A. (2015). Critical success factors for public sector construction project delivery: A case of Owerri, Imo State. International Journal of Research in Management, Science \& Technology (E-ISSN: 2321-3264), 3(1), 11-21.

Ayodeji, O., Eseohe, A., Opeyemi, J., Ebenezer, B., Amusan, L., \& Abisola, O. (2017). Project management a panacea to improving the performance of construction projects in Ogun State, Nigeria. International Journal of Civil Engineering and Technology, 8(9), 12341242.

Chan, W. \& Kumaraswamy, M. M. (2002). A survey of time-cost relationships in Hong Kong construction projects. Building Technology \& Management Journal, 20, 54-72.

Chin, L. S. \& Abdulhamid, A. (2015). The practice of time management on construction project. In the Proceedings of The 5th International Conference of Euro Asia Civil Engineering Forum (EACEF-5), September 2015.

Federal Transit Administration [FTA]. (2012). Construction Project Management Handbook. Washington, DC: U.S. Department of Transportation.

Hao, Q., Shen, W., Neelamkavil, J., \& Thomas, R. (2008). Change management in construction projects. In the Proceedings of International Conference on Information Technology in Construction CIBW78. 15-17 July 2008.

Hussain, H. H. (2014). Time management tools and techniques for project management. Socioeconomic Research Bulletin, 4(55), 57-62.

Ibironke, O. T. \& Elamah, D. (2011). Factors affecting time, cost and quality management in building construction project. FUTY Journal of the Environment, 6(1), 1-9.

Ibrahim, A. B. (2020). Influence of change management practice on construction project performance in Bauchi State. Master Thesis, Abubakar Tafawa Balewa University Bauchi.

Inuwa, I. I. (2014). Project planning in construction procurement: The case of nigerian indigenous contractors. PhD Dissertation, Jomo Kenyatta University of Agriculture and Technology.

John, E. I., Abdullateef, A. S., \& Abdulganiyu, A. O. (2015). A study of time and cost relationship of private building projects in Abuja. International Journal of Construction Engineering and Management, 4(1), 26-34. 
Kwok, A. C. (2014). The Evolution of management theories: A literature Review. Nang Yan Business Journal, 3(1), 28-40.

Mgeleka, N. (2015). Impact of time management on work performance in local government authorities in Tanzania: A case study of Musoma municipal council. Master Thesis, University of Mzumbe Tanzania.

Murithi, S. H., Makokha, E. N., \& Otieno, C. (2017). Factors affecting timely completion of public construction projects in Trans-Nzoia County. International Journal of Scientific and Research Publications, 7(4), 404 - 434.

Olawale, Y. \& Sun, M. (2010). Cost and time control of construction projects: Inhibiting factors and mitigating measures in practice. Construction Management Economics, 28(5), 509526.

Passenheim, O. (2009). Project management. Telluride: Ventus Publishing.

Project Management Institute (PMI). (2013). A guide to the project management body of knowledge (PMBOK guide) 5e.d. Newtown Square, USA: Project Management Institute, Inc.

Project Management Institute (PMI). (2017). Time management. Pennsylvania-USA: Project management institute, Inc.

Sunke, N. (2009). Planning of construction project: A managerial approach. PhD Dissertation, University of Siegen.

Ugwu, O. O. \& Attah, I. O. (2016). An appraisal of construction management practice. Nigerian Journal of Technology (NIJOTECH), 35, 754-760. 